\title{
DEVELOPING THE METHOD OF CONCEPTUAL LINGUISTIC ENGINEERING OF PROFESSIONAL IDENTITY: APPROACHES, ESSENCE, PROSPECTS ${ }^{1}$
}

\author{
Aleksandr Yu. Bagiyan \\ Pyatigorsk State University, Pyatigorsk, Russia \\ Tatyana A. Shiryaeva \\ Pyatigorsk State University, Pyatigorsk, Russia
}

\begin{abstract}
The research object of the paper is professional identity as the integral component of individual's identification matrix, whereas the methodological prerequisites of professional identity's conceptual linguistic engineering act as the research subject. The objective of the research consists in developing new research tools promoting deeper analysis of sociological and linguo-cognitive characteristics of professional identity by means of forming its conceptual framework.

The carried-out critical analysis of theoretical-methodological works devoted to professional identity allows to allocate a number of mainstream approaches to this sphere of studies and to describe a number of key aspects of this sociocultural phenomenon. At the same time, the authors focus their attention on the integral synthesis of the described scientific ideas, which acts as a fundamental basis for developing the method of conceptual linguistic engineering of professional identity. Considering the predominant position of the language in the course of professional identity formation, the fundamental basis of the proposed method is the principle of complex discursive matrix, taking into account a wide number of modern linguistics achievements in the field of discourse analysis, cognitive linguistics, sociolinguistics, psycholinguistics and pragmatics, linguo-axiology, linguo-ecology, and terminology science. Due to the combination of complex linguo-cognitive, socio-lexicographic and pragmaaxiological modeling, as well as systematization and standardization of discourses and their popular scientific subdiscourses, it becomes possible to fill in a number of theoretical and practical gaps. All the above-mentioned helps to offer an algorithm of effective professional cross-cultural interaction in the sphere of critical technologies between the Russian and foreign scientists.
\end{abstract}

Key words: methodology, professional identity, complex technique, discourse, discursive matrix, sciencepopular discourse, conceptual linguistic engineering, sociolinguistics.

Citation. Bagiyan A.Yu., Shiryaeva T.A. Developing the Method of Conceptual Linguistic Engineering of Professional Identity: Approaches, Essence, Prospects. Vestnik Volgogradskogo gosudarstvennogo universiteta. Seriya 2, Yazykoznanie [Science Journal of Volgograd State University. Linguistics], 2018, vol. 17, no. 4, pp. 214-228. (in Russian). DOI: https://doi.org/10.15688/jvolsu2.2018.4.21

УДК 81'42:81'27
Дата поступления статьи: 30.07.2018

Дата принятия статьи: 03.09.2018

\section{МЕТОДИКА КОНЦЕПТУАЛЬНОГО ЛИНГВОПРОЕКТИРОВАНИЯ ПРОФЕССИОНАЛЬНОЙ ИДЕНТИЧНОСТИ: ПОДХОДЫ К РАЗРАБОТКЕ, СУЩНОСТЬ И ПЕРСПЕКТИВЫ ${ }^{1}$}

\author{
Александр Юрьевич Багиян \\ Пятигорский государственный университет, г. Пятигорск, Россия \\ Татьяна Александровна Ширяева \\ Пятигорский государственный университет, г. Пятигорск, Россия
}


Аннотация. Объектом исследования в статье является профессиональная идентичность как неотъемлемый компонент идентификационной матрицы индивида, предметом - комплекс методологических предпосылок концептуального лингвопроектирования профессиональной идентичности. Цель работы заключается в разработке нового исследовательского инструментария, способствующего глубокому анализу социолингвокогнитивных характеристик профессиональной идентичности посредством выстраивания ее концептуального каркаса.

Критический анализ теоретико-методологических работ, посвященных профессиональной идентичности, позволил выделить ряд магистральных подходов к ее изучению и описать ряд ключевых индикаторов данного социокультурного феномена. При этом в фокусе внимания авторов статьи находится возможность органичного синтеза научных идей, который выступает фундаментальной основой для разработки методики концептуального лингвопроектирования профессиональной идентичности. Учитывая доминантный характер языка в процессе формирования профессиональной идентичности, авторы определяют в качестве базиса предлагаемой методики принцип сложной дискурсивной матрицы, реализующийся в совокупности достижений лингвистической науки в области дискурсивного анализа, когнитивной лингвистики, социо-, психои прагмалингвистики, лингвоаксиологии, лингвоэкологии, терминоведения. Перспективность предлагаемой методики обусловлена совмещением комплексного лингвокогнитивного, социолексикографического и прагмааксиологического моделирования, систематизации и стандартизации дискурсов и их научно-популярных субдискурсов, позволяющим заполнить ряд теоретико-практических лакун и предложить алгоритм эффективного профессионального кросскультурного взаимодействия в сфере критических технологий между российскими и зарубежными учеными.

Ключевые слова: методология, профессиональная идентичность, комплексная методика, дискурс, дискурсивная матрица, научно-популярный дискурс, концептуальное лингвопроектирование, социолингвистика.

Цитирование. Багиян А. Ю., Ширяева Т. А. Методика концептуального лингвопроектирования профессиональной идентичности: подходы к разработке, сущность и перспективы // Вестник Волгоградского государственного университета. Серия 2, Языкознание. - 2018. - Т. 17, № 4. - C. 214-228. - DOI: https://doi.org/ 10.15688/jvolsu2.2018.4.21

\section{Введение}

На протяжении последних десятилетий в рамках современной гуманитарной парадигмы проведен целый ряд разнообразных исследований, посвященных изучению феномена идентичности, под которой в самом широком смысле понимается структура эго, то есть внутренняя динамическая самосозидающаяся организация способностей, убеждений, потребностей и индивидуальной истории человека [Эриксон, 2006; Marcia, 1993]. «Нынешний взрыв интереса к идентичности стал ответом на усложнение институциональных основ и стремительный рост многообразия общественной среды, на проявление новых угроз личностному самостоянию и экзистенциальным основаниям жизни человека» [Семененко, 2017а, с. 19]. Термин «идентичность» укоренился в терминологических системах практически всех гуманитарно направленных дисциплин. Его активное употребление в научных публикациях, безусловно, способствовало его стремительному распространению в различных социальных сферах и закреплению в общественном сознании. Все сказанное свидетельствует о востребованности категории идентичности в самом широком диапазоне современного исследовательского поля, которое формируется в процессе изучения ее сущностных характеристик в разных предметных областях.

Однако разнообразие исследований, в которых изучаются сущность и структура идентичности, способствует не только углублению ее понятийного содержания, но и расплывчатости механизмов и конституентов конструирования идентичности с учетом ее постоянных социокультурных изменений. Как справедливо отмечает И.С. Семененко, «фрагментарность и разнородность исследовательского поля идентичности свидетельствуют о том, что здесь образовались незаполненные пока понятийные лакуны» [Семененко, 2017б, с. 11]. Представленные выше аргументы позволяют заключить, что актуальным является поиск комплексной методики исследования категории идентичности.

Одной из таких перспективных методик может стать, на наш взгляд, концепту- 
альное лингвистическое проектирование идентичности с учетом ее сущностных характеристик и гиперо-гипонимических отношений. Принимая во внимание важность профессионального самоопределения и собственно профессионализма как интегрального компонента любого современного индивида, а также то, что в современном обществе сфера профессиональной занятости находится в состоянии перманентных хаотичных, противоречивых и зачастую трудно прогнозируемых трансформаций, обусловливающих кризисную и даже рискогенную ситуацию [Дидковская, 2016 , c. 3], считаем актуальной научной задачей разработку методики лингвистического комплексного анализа именно профессиональной идентичности.

Объектом нашего исследования является профессиональная идентичность как неотъемлемый компонент идентификационной матрицы индивида, предметом - комплекс методологических предпосылок концептуального лингвопроектирования профессиональной идентичности. Цель исследования заключается в разработке нового исследовательского инструментария, способствующего более глубокому анализу социолингвокогнитивных характеристик профессиональной идентичности.

В качестве гипотезы выдвигается положение о том, что социолингвокогнитивная база концептуального каркаса профессиональной идентичности распознается и диагностируется посредством ее концептуального лингвопроектирования, заключающегося в лингвокогнитивном, социолексикографическом, прагмааксиологическом и лингвоэкологическом моделировании соответствующего профессионального дискурса и его научно-популярной составляющей.

Исследование основано на критическом анализе теоретико-методологических работ в области изучения профессиональной идентичности, проведено с применением междисциплинарного дефиниционного анализа термина «профессиональная идентичность», стратификационного анализа ключевых подходов к пониманию профессиональной идентичности в ее общегуманитарном и лингвокоммуникативном плане.

\section{Понятие}

«профессиональная идентичность» в современной гуманитарной парадигме

Описание новой методики исследования профессиональной идентичности (ПИ) требует прежде всего характеристики данного феномена, выделения его основных черт. Проведенный критический анализ теоретико-методологических работ, посвященных ПИ, позволил выделить ряд магистральных подходов к ее изучению.

Поскольку термин «профессиональная идентичность» возник в рамках психологии личности, логичным представляется начать характеристику направлений изучения профессиональной идентичности именно с психологического подхода. В соответствии с существующими психологическими концепциями профессиональная идентичность определяется в качестве многоуровневой личностной динамической структуры, включающей как осознаваемые, так и неосознаваемые элементы и выражающей объективно-субъективное единение индивида с той или иной профессиональной группой, а также обеспечивающей внутреннюю целостность и тождественность индивида на каждом этапе профессионального развития с учетом преемственности и темпоральной устойчивости профессиональных характеристик [Зеер, Сыманюк, 2005; Маркова, 1996; Шнейдер, 2007; Orlofsky, Marcia, Lesser, 1973; Waterman, 1982].

Становление идентичности, как показано А.К. Марковой, находит свое непосредственное выражение в увеличении количества отражающихся в сознании каждого специалиста признаков профессиональных отношений и профессиональной деятельности, в преодолении различных стереотипов профессионального образа, а также в целостном осознании индивидом своего места в контексте его непосредственной профессиональной деятельности [Маркова, 1996, с. 85-87]. Более того, как утверждает Е.П. Ермолаева, значение профессиональной идентичности сложно переоценить, поскольку последняя обеспечивает необходимый уровень устойчивой профессионально-ментальной позиции и профессионального центризма, без которых достижение высшей ступени профессионально- 
го мастерства не представляется возможным [Ермолаева, 2001].

Согласно исследованиям в области педагогической психологии становление профессиональной идентичности находится в прямой корреляционной зависимости от гетерохронного развития ее различных компонентов [Денисова, 2008, с. 5]. Рассматривая специфику врачебной профессии, О.В. Денисова отмечает, что становление профессиональной идентичности будущего специалиста выступает в качестве важнейшего звена его профессиональной подготовки. Содержание ПИ предопределено особенностями каждой отдельной профессии. Они раскрываются в таких компонентах ПИ, как личность профессионала, профессиональная деятельность, профессиональное общение, а также в морально-нравственном компоненте профессии, который является системообразующим в структуре профидентичности [Денисова, 2008, с. 8-9].

В исследованиях Д.А. Исаевой и Т.В. Малютиной на основе сегментирования основных предпосылок формирования профессиональной идентичности выявлено, что базовыми детерминантами ее становления могут выступать следующие компоненты: притязания субъекта, удовлетворенность выбранной профессией, самооценка, ценностные ориентации и ответственность индивида [Исаева, 2013; Малютина, 2014].

В рамках социологического подхода понятие «идентичность» исследуется унифицированными методами описания, анализа и прогнозирования процессов и структурируется в соответствии с триадой «общество $\leftrightarrow$ социальная группа $\leftrightarrow$ личность». Как отмечают многие ученые, наполнение центрального элемента представленной триады категориальным смыслом предопределяет типизацию личных черт и характеристик, механизмов и результатов идентификации и социализации индивида, а также характер и глубину специфических социальных взаимодействий [Заковоротная, 1999; Мухортова, 2015; Jenkins, 2008].

Предложенная триада отражает одну из отличительных черт данного подхода: конвергенцию понятия «профессиональная идентичность» с такими ключевыми направлениями исследования в социологической науке, как профессиональная карьера, социальные механизмы регулирования общественных явлений и процессов, профессиональные и карьерные стратегии (их формирование и реализация), трансформационные современные общественные процессы [Данилова, Ядов, 2004; Дидковская, 2014; Чередниченко, 2014; Шубкин, Бабушкина, 1986].

Исключительная значимость социальной составляющей исследуемого феномена подчеркивается введением помимо уже существовавшего термина «социальная идентичность» [Ганеева, 2008; Лескова, 2008; Parsons, 1966] термина «социопрофессиональная идентичность», толкуемого как одновременно процесс и результат конструирования индивидом «Я»-образа с целью достижения самоактуализации в рамках его профессиональной деятельности. В качестве содержания такого образа выступает согласование жизненных и профессиональных представлений индивида, а также соотнесение его социального «Я» с ценностным, нормативным, культурным, информационным, символическим и коммуникативным полями профессиональной практики [Сухова, 2013, с. 14].

Исследуя социопрофессиональную идентичность, социологи, как правило, опираются на ряд индикаторов данного феномена: на микроуровне - это удовлетворенность, мотивация и ожидания; на мезоуровне - структура и действие; на макроуровне - профессиональное сообщество, социальные институты, автономия; сквозными индикаторами являются взаимодействие, конфликт, ценности, знание [Гидденс, 2005; Сухова, 2013; Freidson, 1970]. Здесь важно подчеркнуть, что при рассмотрении сути процесса формирования профессиональной идентичности как ключевого аспекта современной социальной идентичности обязателен учет коллективной временной детерминации, под которой понимается комплекс целей определенного коллектива вместе с некоторыми допустимыми средствами их достижения для коллективной самореализации в исторической перспективе [Заковоротная, 2014, с. 21].

При педагогическом подходе феномен профессиональной идентичности рассматривается в совокупности с понятиями «профессиональное сознание», «профессиональный выбор» и «профессиональное самоопределе- 
ние». Отличительной чертой данного подхода является ранжирование этапов формирования профессиональной идентичности в соответствии со ступенями образовательного процесса (от начальной до высшей школы) [Жигинас, 2007; Миронова, 2015]. Примечательно, что различные подходы к исследованию профессиональной идентичности в рамках ее педагогической обусловленности структурно-институциональный (М.П. Щербакова, С.Л. Ивашевский и др.) и профессионально-образовательный (А.В. Федоров, Е.И. Мычко и др.) - приводят к единому пониманию природы этого феномена. Согласно структурно-институциональному подходу профессиональная идентичность определяется как «совокупность двух “контуров" ее тождественности»: внутреннего (тождественности собственному представлению индивида о его профессиональном призвании, ценностям и нормам) и внешнего (соответствия требованиям гражданского общества и социального окружения) [Щербакова, 2015, с. 6]. Понимание исследуемой идентичности в рамках профессионально-образовательного подхода перекликается с ее пониманием в рамках социологического подхода, где ПИ трактуется как интегративное качество личности, соединяющее в себе субъективное переживание индивида относительно тождественности своей профессии и профессиональной группе, а также тождественности определенному набору профессиональных ролей [Федоров, 2017, с. 11]. При этом в фокусе внимания исследователей ПИ в русле педагогического подхода находится алгоритм выстраивания модели формирования профессиональной идентичности различных возрастных и образовательных групп на основе некоего профессионального стандарта или ФГОСа с применением социально-ролевого, аксиологического и деятельностного подходов [Красникова, 2015; Федотова, 2009].

При этнокультурологическом подходе к изучению профессиональной идентичности внимание исследователей фокусируется на изначально имеющейся культурной идентичности индивида, претерпевающей аккультурацию, которую, по мнению Е.В. Воеводы, следует рассматривать как компонент межкультурной коммуникации, приводящий к «значительным изменениям в культурных формах жизнедеятельности личности и на национальном уровне, и в ежедневной языковой практике» [Воевода, 2012, с. 172-173]. Такие изменения связаны с погружением индивида в другую языковую картину мира, в результате чего у него формируются иные, отличные от прежних, мировосприятие и система ценностей, то есть человек неизбежно подвергается влиянию определенной иноязычной культуры [Boевода, 2012, с. 173; Романенко, 2014, с. 314].

Лингвистический подход к изучению ПИ базируется на понимании того, что становление профессионала, формирование его профессиональной идентичности, развитие его профессионального самосознания нельзя рассматривать вне языка. В последние десятилетия неоднократно предпринимались попытки комплексного лингвистического исследования идентичности индивида (см., например: [Лингвистические аспекты..., 2012; Цапко, 2017 и др.]), равно как и попытки узконаправленного лингвистического анализа определенных видов идентичности: национально-культурной [Жерновая, 2016], гендерной [Куракина, 2014], религиозной [Акбарйан, 2009], политической [Корнеева, 2016], этнической [Батнасунов, 2014] и др. Тем не менее профессиональная личность в качестве объекта языковедческого исследования затрагивалась «по касательной» как один из элементов, необходимых для более глубокого понимания общей самоидентификации личности (ср.: [Загуменнов, 2017]).

В лингвистических исследованиях показано, что профессиональная идентичность имеет осложненную структуру. По мнению Е.Н. Азначеевой, с лингвистической точки зрения внутренняя типологизация профессиональной идентичности может быть осуществлена на основе комплекса параметров. В качестве ключевых ученый выделяет следующие: доминантный тип знания (когнитивный уровень); значимость учета мировоззренческого компонента при осуществлении профессиональной деятельности; развитие и использование профессионального лексикона; стилистические характеристики неофициальной профессиональной коммуникации; (не)совпадение объема понятий «профессиональная личность» и «языковая личность профессионала» [Азначеева, 2012, с. 6]. 
Неразрывная связь профессиональной и социальной идентичностей подчеркивается в исследовании В. Гудикунста, по мнению которого принадлежность индивида к определенной профессиональной группе оказывает существенное влияние на его социальную идентичность, что непременно находит отражение в языковой реализации личности [Gudykunst, 2012, p. 77].

В качестве базового компонента при обретении индивидом его профессиональной идентичности многие ученые рассматривают освоение профессионального лексикона, отмечая межъязыковое сходство различных терминологических аппаратов и национально-этническое своеобразие терминосистем различных языков [Колмогорова, 2016; Солнышкина, Исмагилова, Шигапова, 2015; Солнышкина, Шигапова, Габдрахманова, 2015]. При этом утверждается, что индивид способен одновременно или последовательно принадлежать к целому ряду социальных и профессиональных сообществ, проходя, таким образом, лингвистическую аккультурацию. В этом случае идентичность индивида, будучи социолингвистической категорией, «должна рассматриваться как мультиполярная структура, спектр поведенческих скриптов которой находится в диапазоне “мультиполярного континуума", в котором один полюс - интеракции, детерминированные только индивидуальными характеристиками личности, а все другие полюсы - коммуникации между лицами, определяемые их принадлежностью к кой-либо группе или сообществу» [Солнышкина, Шигапова, Габдрахманова, 2015, с. 154].

Философский подход к изучению профессиональной идентичности, имея комплексную методологическую основу, может реализоваться в трех аспектах: экзистенциальном - осмысление проблемы самоопределения при выборе собственной личностной и частично профессиональной идентичности (М. Хайдеггер, К. Ясперс, Ж-П. Сартр и др.), этическом - сопряжение самоопределения с поиском смысла жизни (М. Бахтин, И. Ильин, Н. Бердяев и др.), профессиональном - понимание профессионального самоопределения как важнейшего элемента общей самоидентификации личности (В.В. Байлука, П.П. Гайденко, И.С. Кон и др.). Подробно об этих аспектах см.: [Патырбаева и др., 2012; Разлогов, 2015].
Систематизация результатов исследования ПИ в русле разных подходов к пониманию природы этого феномена представлена в таблице 1.

Таким образом, профессиональная идентичность - это феномен, который характеризуется комплексной структурой, что определяет многоаспектную направленность исследовательских парадигм. Однако на сегодняшний день попытки создания комплексной лингвистической методики изучения рассматриваемого феномена, которая бы учитывала достижения каждого из представленных подходов, еще не предпринимались. Именно эту задачу мы и ставим в работе.

\section{Комплексность как основа методики концептуального лингвопроектирования профессиональной идентичности}

Разработка теоретических оснований концептуального лингвопроектирования ПИ и создание комплексной методики исследования, инкорпорирующей достижения каждого из обозначенных подходов, представляется сложной задачей, которая соотносится не только с языковыми аспектами формирования ПИ, но и с рядом экстралингвистических вопросов, каждый из которых требует особого внимания.

Учитывая доминантный характер языка при описании процесса формирования ПИ, считаем фундаментом новой методики принцип сложной дискурсивной матрицы, реализующийся в совокупности современных наработок в области дискурсивного анализа, когнитивной лингвистики, социо-, психо- и прагмалингвистики, лингвоаксиологии, лингвоэкологии, терминоведения, находящихся в корреляции с представленными ранее подходами и имеющих точки пересечения с лингвистической экспертизой персонотекстов (см.: [Ионова, 2017]). В настоящее время только комплексный многофакторный анализ лингвистической составляющей профессиональной идентичности индивида (специалиста / дилетанта), включающий методы каждой из перечисленных областей языкознания, может претендовать на валидность и теоретико-практический исследовательский потенциал, а полученные результаты - на верифицируемость. Предлагаемая методика кон- 


\section{Общая характеристика подходов к пониманию термина «профессиональная идентичность» (ПИ)}

\begin{tabular}{|c|c|c|}
\hline Подход & $\begin{array}{c}\text { Основные } \\
\text { представители }\end{array}$ & Основные достижения \\
\hline Психологический & $\begin{array}{l}\text { Денисова О.В. } \\
\text { Ермолаева Е.П. } \\
\text { Зеер Э.Ф. } \\
\text { Исаева Д.А. } \\
\text { Малютина Т.В. } \\
\text { Маркова А.К. } \\
\text { Сыманюк Э.Э. } \\
\text { Шнейдер Л.Б. } \\
\text { Mагсіа J.E. } \\
\text { Lesser L.M. } \\
\text { Orlofsky J.L. } \\
\text { Waterman A.S. }\end{array}$ & $\begin{array}{l}\text { - ПИ - это многоуровневая личностная структура динамического } \\
\text { характера, обеспечивающая внутреннюю целостность индивида; } \\
\text { - ПИ формирует необходимый уровень устойчивой профессио- } \\
\text { нально-ментальной позиции и профессионального центризма; } \\
\text { - становление ПИ взаимосвязано с гетерохронным развитием ее } \\
\text { различных составляющих; } \\
\text { - формирование ПИ является важнейшим элементом профессио- } \\
\text { нальной подготовки; } \\
\text {-системообразующим компонентом ПИ является морально- } \\
\text { нравственная составляющая; } \\
\text { - детерминантами становления ПИ выступают притязания субь- } \\
\text { екта, удовлетворенность выбранной профессией, самооценка, } \\
\text { ценностные ориентации и ответственность индивида }\end{array}$ \\
\hline Социологический & $\begin{array}{l}\text { Гидденс Э. } \\
\text { Дидковская Я.В. } \\
\text { Лескова И.В. } \\
\text { Мухортова В.Н. } \\
\text { Семененко И.С. } \\
\text { Сухова Е.Н. } \\
\text { Чередниченко Г.А. } \\
\text { Шубкин В.Н. } \\
\text { ЯдовВ. } \\
\text { Parsons Т. } \\
\text { FreidsonЕ. } \\
\text { Jankins R. }\end{array}$ & $\begin{array}{l}\text { - ПИ - это процесс конструирования индивидом «Я»-образа в } \\
\text { рамкахопределенной профессии и соотнесение социального «Я»с } \\
\text { комплексными нормативно-ценностной, культурно-символи- } \\
\text { ческой, информационно-коммуникативной сферами профессио- } \\
\text { нальной практики; } \\
\text { - ПИ базируется на триаде «общество } \Leftrightarrow \text { социальная группа } \Leftrightarrow \\
\text { личность» и реализуется в ней; } \\
\text { - специфичные идентификаторы ПИ имеют многоуровневую ди- } \\
\text { версификацию; } \\
\text { - неотъемлемым компонентом любого анализа ПИ является со- } \\
\text { циологическая составляющая }\end{array}$ \\
\hline Педагогический & $\begin{array}{l}\text { Жигинас Н. } \\
\text { Ивашевский С.Л. } \\
\text { Красникова Ю.В. } \\
\text { Миронова С.П. } \\
\text { Мьччо Е.И. } \\
\text { Федоров А.В. } \\
\text { Федотова Л.М. } \\
\text { Щербакова М.П. }\end{array}$ & $\begin{array}{l}\text { - ПИ есть совокупная тождественность личности ее личностному } \\
\text { и социально-институциональному самовосприятию; } \\
\text { - включение элементов развития профессионального самосозна- } \\
\text { ния и профессиональной идентичности обязательно для образова- } \\
\text { тельного процесса; } \\
\text { - ранжирование этапов формирования ПИ возможно в соответст- } \\
\text { вии со ступенями образовательного процесса; } \\
\text { - основная задача состоит в выстраивании модели формирования } \\
\text { профессиональной идентичности различных возрастных и образо- } \\
\text { вательных групп на основе профессиональных стандартов }\end{array}$ \\
\hline $\begin{array}{l}\text { Этнокультуроло- } \\
\text { гический }\end{array}$ & $\begin{array}{l}\text { Воевода Е.В. } \\
\text { Романенко Н.M. }\end{array}$ & $\begin{array}{l}\text { - на ПИ влияет аккультурация; } \\
\text { - необходима выработка стратегии параллельной интеграции }\end{array}$ \\
\hline Лингвистический & $\begin{array}{l}\text { Азначеева Е.Н. } \\
\text { Солньикина М.И. } \\
\text { Шигапова Ф.М. } \\
\text { Гардрахманова Р.P. } \\
\text { Колмогоров А.В. } \\
\text { Gudykипst W.В. }\end{array}$ & $\begin{array}{l}\text { - на социальную идентичность индивида влияет его принадлеж- } \\
\text { ность к определенной профессиональной группе; } \\
\text { - ПИ имеет осложненную структуру, характеризующуюся ком- } \\
\text { плексом когнитивных, мировоззренческих и лексико-стилисти- } \\
\text { ческих параметров; } \\
\text { - базовым элементом обретения индивидом ПИ является освоение } \\
\text { профессиональной лексики; } \\
\text { - индивид способен одновременно/последовательно принадле- } \\
\text { жать к ряду социальных и профессиональных сообществ, проходя } \\
\text { лингвистическую аккультурацию }\end{array}$ \\
\hline Философский & $\begin{array}{l}\text { Байлука В.В. } \\
\text { Патьирбаева К.В. } \\
\text { Разлогов К.Э. }\end{array}$ & $\begin{array}{l}\text { - профессиональное самоопределение понимается как интеграль- } \\
\text { ный компонент самоидентификации личности; } \\
\text { - ПИ рассматривается в экзистенциальном, этическом и профес- } \\
\text { сиональном аспектах }\end{array}$ \\
\hline
\end{tabular}

цептуального лингвопроектирования профессиональной идентичности призвана, с одной стороны, заполнить ряд теоретико-практических лакун, а с другой стороны, может обеспечить эффективное профессиональное кросскультурное взаимодействие в сфере критических технологий между российскими и зарубежными учеными. В результате осуществления концеп- 
туального лингвопроектирования профессиональной идентичности специалистов, включающего в себя такие этапы, как комплексное лингвокогнитивное, социолексикографическое и прагмааксиологическое моделирование, систематизация и стандартизация профессиональных дискурсов и их научно-популярных субдискурсов, научное сообщество и те, кто работает в реальном секторе экономики, получают возможность более глубокого понимания процес- сов возникновения и развития «внутреннего чувства идентичности» у представителей определенной профессии, формирующего единую систему координат личности в различных сферах жизни.

Предлагаемая методика концептуального лингвопроектирования профессиональной идентичности учитывает, как показано на схеме, основные достижения каждого из общегуманитарных подходов: лингвокогни-

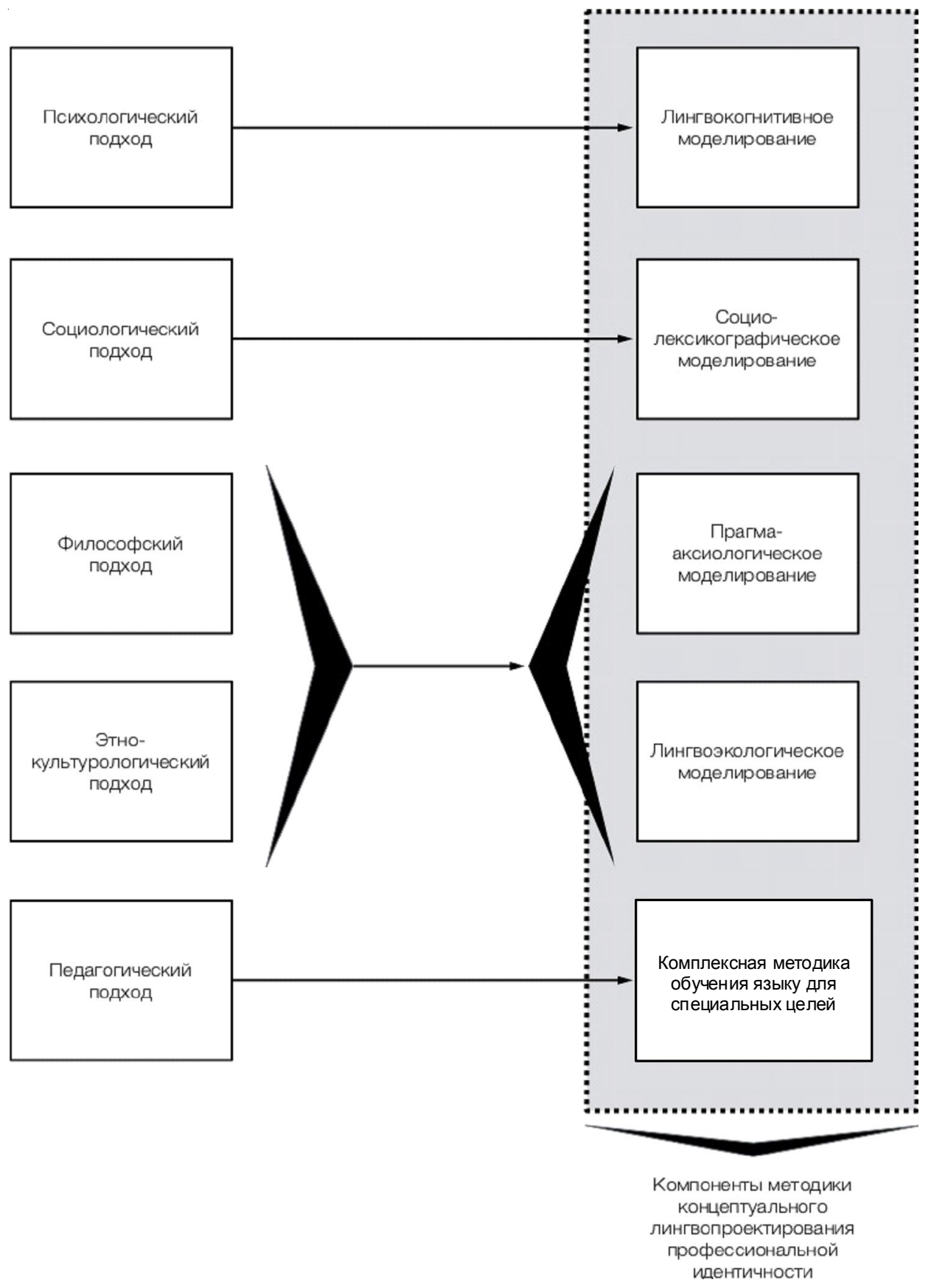

Корреляция общегуманитарных направлений исследования ПИ с элементами методики концептуального лингвопроектирования ПИ 
тивное моделирование основывается в значительной степени на психологическом подходе, социолексикографическое моделирование - на социологическом подходе, в прагмааксиологическое и лингвоэкологическое моделирование включены элементы философского и этнокультурологического подходов, педагогический подход представлен комплексной методикой исследования языковых явлений для преподавания языка в специальных целях. Таким образом, предлагаемая методика концептуального лингвопроектирования профессиональной идентичности объединяет существующие подходы к изучению профессиональной идентичности при ее исследовании сквозь призму языка.

Несмотря на новизну методики концептуального лингвопроектирования професси- ональной идентичности и тот факт, что она все еще находится на стадии разработки, считаем необходимым обозначить примерный поэтапный алгоритм ее реализации с указанием используемых приемов и методов анализа, а также основными задачами, решение которых необходимо для достижения основной цели предлагаемой методики (см. табл. 2).

Безусловно, данная методика требует дальнейшей апробации при комплексном изучении различных видов дискурса. Подчеркнем, что авторами планируется проведение целого ряда исследований на материале профессионального и научно-популярного дискурсов различной тематической направленности с целью верификации и дальнейшего усовершенствования представленной методики.

Таблииа 2

\section{Примерный алгоритм проведения анализа языкового материала по методике} концептуального лингвопроектирования профессиональной идентичности

\begin{tabular}{|c|c|c|}
\hline Эman & Методы и приемы & Задачи \\
\hline \multirow[t]{3}{*}{$\begin{array}{l}\text { Сбор фактическо- } \\
\text { го материала }\end{array}$} & $\begin{array}{l}\text { сплошная выборка фактического языкового } \\
\text { материала }\end{array}$ & \multirow{3}{*}{$\begin{array}{l}\text { - категоризация фактическо го языкового } \\
\text { материала и создание корпуса данных; } \\
\text { - создание структуры сложной дискурсив- } \\
\text { ной матрицы для ее последущего заполне- } \\
\text { ния новыми данными }\end{array}$} \\
\hline & контекстуальный анализ & \\
\hline & $\begin{array}{l}\text { поэтапная классификация фактического } \\
\text { языкового материала }\end{array}$ & \\
\hline \multirow{5}{*}{$\begin{array}{l}\text { Лингвокогнитив- } \\
\text { ное моделирова- } \\
\text { ние }\end{array}$} & анализ дефиниций / толкований & \multirow{2}{*}{$\begin{array}{l}\text { - разложение дефиниций / толкований на } \\
\text { с емантические компоненты }\end{array}$} \\
\hline & $\begin{array}{l}\text { компонентный анализ семантической } \\
\text { структуры }\end{array}$ & \\
\hline & выстраивание семантических оппозиций & \multirow{2}{*}{$\begin{array}{l}\text { - выявление точек роста терминофонда / } \\
\text { лексического состава; } \\
\text { - выявление семантической структуры } \\
\text { термина / лексической единицы }\end{array}$} \\
\hline & $\begin{array}{l}\text { ядерно-периферийное семантическое моде- } \\
\text { лирование }\end{array}$ & \\
\hline & $\begin{array}{l}\text { фреймовый анализ данных профессиональ- } \\
\text { ного / научно-популярного дискурса }\end{array}$ & $\begin{array}{l}\text { - создание когнитивной модели, отражаю- } \\
\text { щей базовые концепты исследуемой области; } \\
\text { - выявление корреляции базовых концеп- } \\
\text { тов в профессиональном и научно-популяр- } \\
\text { ном дискурсах }\end{array}$ \\
\hline \multirow{5}{*}{$\begin{array}{l}\text { Прагмааксиоло- } \\
\text { гическое модели- } \\
\text { рование }\end{array}$} & дискурс-анализ & \multirow{4}{*}{$\begin{array}{l}\text { - выявление корреляции функционального } \\
\text { диапазона в профессиональном и научно- } \\
\text { популярном дискурсах; } \\
\text { - выявление особенностей лингвокреатив- } \\
\text { ной реализации языковых единиц }\end{array}$} \\
\hline & прагмакоммуникативный анализ & \\
\hline & $\begin{array}{l}\text { функциональный анализ всего комплекса } \\
\text { языковых единиц в профессиональном узусе }\end{array}$ & \\
\hline & $\begin{array}{l}\text { функщиональный анализ всего комплекса } \\
\text { языковых единиц в научно-популярном } \\
\text { узусе }\end{array}$ & \\
\hline & лингвоаксиологический анализ & $\begin{array}{l}\text { - определение ценностно-доминантных } \\
\text { сфер в профессиональном и научно- } \\
\text { популярном дискурсах }\end{array}$ \\
\hline $\begin{array}{l}\text { Лингвоэкологиче- } \\
\text { ское моделирова- } \\
\text { ние }\end{array}$ & $\begin{array}{l}\text { анализ лингвоэколо гичности научного и } \\
\text { научно-популярного дискурсов }\end{array}$ & $\begin{array}{l}\text { - определение уровня контаминации про- } \\
\text { фессионально го и научно-популярного } \\
\text { дискурсов; } \\
\text { - определение целесообразности использо- } \\
\text { вания языковой единицы в определенном } \\
\text { дискурсивном пространстве }\end{array}$ \\
\hline
\end{tabular}


Окончание таблицы 2

\begin{tabular}{|c|c|c|}
\hline Эman & Методы и приемы & Задачи \\
\hline \multirow[t]{3}{*}{$\begin{array}{l}\text { Социолексико- } \\
\text { графическое мо- } \\
\text { делирование }\end{array}$} & социокогнитивное моделирование & $\begin{array}{l}\text { - установление взаимосвязи между когни- } \\
\text { тивной деятельностью профессионала / ди- } \\
\text { летанта и репрезентацией знаний, накоп- } \\
\text { ленных в языке исследуемого социального } \\
\text { института }\end{array}$ \\
\hline & тезаурусное моделирование & \multirow{2}{*}{$\begin{array}{l}\text { - корректное структурирование словарной } \\
\text { статьи; } \\
\text { - выявление системных связей в рамках } \\
\text { исследуемой тематической области }\end{array}$} \\
\hline & элементы электронной лексикографии & \\
\hline \multirow[t]{2}{*}{$\begin{array}{l}\text { Статистическое } \\
\text { моделирование }\end{array}$} & квантитативный анализ & $\begin{array}{l}\text { - возможность использования всего накоп- } \\
\text { ленного корпуса данных для предоставле- } \\
\text { ния наиболее полной информации в сло- } \\
\text { варной статье }\end{array}$ \\
\hline & лингвостатистический анализ & $\begin{array}{l}\text { - получение количественных показателей } \\
\text { (частотности употребления, процентного } \\
\text { содержания каждой категории и т. д.) для } \\
\text { дополнения словарной статьи и корпуса } \\
\text { данных }\end{array}$ \\
\hline $\begin{array}{l}\text { Анализ апплика- } \\
\text { тивнойвалидно- } \\
\text { сти материала }\end{array}$ & $\begin{array}{l}\text { контент-анализ выявленного корпуса дан- } \\
\text { ных с позиций когнитивно-коммуникатив- } \\
\text { ного профессионально-ориентированного } \\
\text { подхода к преподаванию иностранного } \\
\text { языка }\end{array}$ & $\begin{array}{l}\text { - обнаружение наиболее значимых элемен- } \\
\text { тов, необходимых для использования при } \\
\text { создании учебно-методического комплекса } \\
\text { по иностранному языку для специалистов в } \\
\text { исследуемой области }\end{array}$ \\
\hline
\end{tabular}

\section{Заключение}

Итак, нами проведен анализ понятия «профессиональная идентичность» в современной гуманитарной парадигме, который позволил систематизировать основные подходы к пониманию природы данного явления и с учетом результатов исследований, выполненных в русле каждого из подходов, предложить комплексную методику концептуального лингвопроектирования профессиональной идентичности.

Представленная методика перспективна, поскольку, во-первых, основывается на синтезе различных гуманитарных концепций, что обеспечивает валидность и верифицируемость полученных выводов; во-вторых, парадигмальная и методологическая разноплановость лингвистической науки демонстрируют значительно большие возможности для диагностики профессиональной идентичности, равно как и механизмов ее формирования; в-третьих, углубление и совершенствование теоретического осмысления с лингвистических позиций феномена «профессиональная идентичность», выступающего и как сложный многоаспектный конструкт, и как конституирующий фрагмент национальной картины мира имеет большое значение для практической работы в сфере международного профессионального сотрудничества; в-четвертых, ее использование будет способствовать развитию актуальных направлений современного языкознания.

\section{ПРИМЕЧАНИЕ}

${ }^{1}$ Публикация выполнена в рамках проекта «Концептуальное лингвопроектирование профессиональной идентичности в инновационной экономике: лингвокогнитивное, социо-лексикографическое и прагма-аксиологическое моделирование русскоязычного и западноевропейского научно-популярного дискурса» по гранту Президента Российской Федерации (№ МК-6895.2018.6; руководитель А.Ю. Багиян).

\section{СПИСОК ЛИТЕРАТУРЫ}

Азначеева Е. Н., 2012. Введение // Лингвистические аспекты исследования идентичности личности в изменяющемся мире : коллект. моногр. / под ред. Е. Н. Азначеевой. Челябинск : Энциклопедия. С. 4-7.

Акбарйан Ф. Е., 2009. К проблеме чувства собственного достоинства и его взаимосвязи с религиозной идентичностью у подростков // Вопросы филологических наук. № 5. С. 217-222.

Батнасунов А. С., 2014. Этническая идентичность молодежи полиэтничного региона как элемент 
гражданской идентичности // Мир науки, культуры, образования. № 3 (46). С. 298-299.

Воевода Е. В., 2012. Контактные языки как лингвокультурная доминанта на постсоветском пространстве // Вестник МГИМО-Университета. № 6 (27). C. 172-175.

Ганеева Е. И., 2008. Проблемная социальная идентичность: сущность и условия формирования // Вестник Нижегородского университета им. Н.И. Лобачевского. № 1 (9). С. 39-45.

Гидденс Э., 2005. Устроение общества: Очерк теории структурации. 2-е изд. М. : Академический Проект. 528 с.

Данилова Е., Ядов В., 2004. Контекстуально-лабильная социальная идентичность - норма современных динамичных обществ // СОЦИС. № 10. C. 27-30.

Денисова О. В., 2008. Становление профессиональной идентичности студента-медика в образовательном процессе вуза : автореф. дис. ... канд. психол. наук. Екатеринбург. 26 с.

Дидковская Я. В., 2014. Динамика стратегий профессиональной карьеры молодежи в условиях трансформации модели профессионального самоопределения // Известия Уральского федерального университета. Серия 1: Проблемы образования, науки и культуры. Т. 126, №2. С. 117-131.

Дидковская Я. В., 2016. Трансформация социального механизма взаимосвязи профессионального самоопределения и профессиональной карьеры в российском обществе : дис. ... д-ра социол. наук. Екатеринбург. 327 с.

Ермолаева Е. П., 2001. Профессиональная идентичность и маргинализм: концепция и реальность (статья первая) // Психологический журнал. T. 22, № 4. C. 51-59.

Жерновая О. Р., 2016. Современный образ «британских» шотландцев в английских этнических шутках и анекдотах в контексте противостояния национально-культурных идентичностей // Современные исследования социальных проблем. № 3-2 (27). С. 175-194.

Жигинас Н., 2007. Этапы формирования профессиональной идентичности педагога // Высшее образование в России. № 8. С. 121-122.

Загуменнов А. В., 2017. Герменевтико-феноменологический аспект изучения языковой личности: к постановке проблемы // Вестник Волгоградского государственного университета. Серия 2, Языкознание. Т. 16, № 1. С. 144-153. DOI: 10.15688/jvolsu2.2017.1.15.

Заковоротная М. В., 1999. Идентичность человека: социально-философские аспекты. Ростов н/Д : Изд-во Северо-Кавказ. науч. центра высш. шк. 200 с.
Заковоротная М. В., 2014. Профессиональная идентичность как ключевой аспект современной социальной идентичности // Вестник Адыгейского государственного университета. № 3 (144). C. 13-22.

Зеер Э. Ф., Сыманюк Э. Э., 2005. Психология профессиональных деструкций. М. : Академический проект ; Екатеринбург : Деловая книга. $240 \mathrm{c}$.

Ионова С. В., 2017. Аспекты исследования письменного текста как объекта лингвистической экспертизы // Вестник Волгоградского государственного университета. Серия 2, Языкознание. Т. 16, № 2. С. 28-38. DOI: 10.15688/jvolsu2. 2017.2.3.

Исаева Д. А., 2013. Особенности личностной и профессиональной идентичности в юности и ранней взрослости // Вестник Санкт-Петербургского университета. Серия 12. Психология. Социология. Педагогика. № 2. С. 78-85.

Колмогорова А. В., 2016. Термин как средство конструирования идентичности в профессиональной коммуникации // Вестник Челябинского государственного университета. № 4 (386). C. 69-73.

Корнеева В. А., 2016. Спортивные символы как инструмент формирования и трансформации политических идентичностей регионов // Политическая лингвистика. Вып. 1 (55). С. 93-98.

Красникова Ю. В., 2015. Структура и содержание профессиональной идентичности будущих специалистов в образовательной среде техникума // Профессиональное образование в России и за рубежом. № 4 (20). С. 67-73.

Куракина Н. А., 2014. Влияние кризиса гендерной идентичности на выражение комплиментарных высказываний представителями английской, американской и русской национальных идентичностей // Филологические науки. Вопросы теории и практики. № 5 (35), ч. 2. C. $122-126$.

Лескова И. В., 2008. Трансформация социальной идентичности в российском обществе: социологический анализ. М. : Изд-во РГСУ «Союз». $374 \mathrm{c}$.

Лингвистические аспекты..., 2012. Лингвистические аспекты исследования идентичности личности в изменяющемся мире : коллект. моногр. / под ред. Е. Н. Азначеевой. Челябинск : Энциклопедия. $232 \mathrm{c}$.

Малютина Т. В., 2014. Профессиональная идентичность, ее структура и компоненты // Омский научный вестник. № 5 (132). С. 149-152.

Маркова А. К., 1996. Психология профессионализма. М. : Международный гуманитарный фонд «Знание». 312 с. 
Миронова С. П., 2015. Современные инновационные технологии формирования профессионального сознания в системе вывшего образования. Екатеринбург : Изд-во Рос. гос. проф.-пед. ун-та. 179 с.

Мухортова В. Н., 2015. Особенности социологического подхода к понятию «профессиональная идентичность» // Социум и власть. № 3 (53). C. 9-13.

Патырбаева К. В. и др., 2012. Идентичность: социально-психологические и социально-философские аспекты : коллект. моногр. / К. В. Патырбаева [и др.]. Пермь : Перм. гос. нац. исслед. ун-т. 250 с.

Разлогов К. Э., 2015. Метаморфозы идентичности // Вопросы философии. № 7. С. 28-40.

Романенко Н. М., 2014. Особенности аккультурации в профессиональной деятельности специалиста-международника // Вестник МГИМО-Университета. № 4. С. 312-316.

Семененко И. С., 2017а. Категория идентичности в социальных науках: понятие, когнитивный потенциал, приоритеты исследований // Идентичность: Личность, общество, политика. Энциклопедическое издание / отв. ред. И. С. Семененко. М. : Весь Мир. С. 18-32.

Семененко И. С., 2017б. Предисловие // Идентичность: Личность, общество, политика. Энциклопедическое издание / отв. ред. И. С. Семененко. М. : Весь Мир. С. 11-17.

Солнышкина М. И., Исмагилова А. Р., Шигапова Ф. Ф., 2015. Либерализм эргономикона как угроза лингвокультурной идентичности (на примере современной Казани) // Вестник Волгоградского государственного университета. Серия 4. История. Регионоведение. Международные отношения . № 5 (29). С. 34-39. DOI: 10.15688/jvolsu2.2015.5.4.

Солнышкина М. И., Шигапова Ф. М., Габдрахманова Р. Р., 2015. Лингвистические маркеры этнолингвистической и профессиональной идентичности // Филология и культура. № 4 (42). C. $150-156$.

Сухова Е. Н., 2013. Трансформация социопрофессиональной идентичности в медицине : автореф. дис. ... канд. социол. наук. Нижний Новгород. 22 с.

Федоров А. В., 2017. Педагогическая модель формирования профессиональной идентичности бакалавров социальной работы в вузе // Глобальный научный потенциал. № 8 (77). C. $10-12$.

Федотова Л. М., 2009. Общие закономерности формирования профессиональной идентичности // Альманах современной науки и образования. № 10, ч. II. С. 118-120.
Цапко М. И., 2017. Языковая идентичность как объединяющая идентичность: в поиске конструирующих методологических стратегий // Язык и культура в эпоху интеграции научного знания и профессионализации образования : материалы междунар. науч.-практич.й конф. С. 229-235.

Чередниченко Г. А., 2014. Образовательные и профессиональные траектории молодежи. М. : ЦСП и М. 560 с.

Шнейдер Л. Б., 2007. Личностная, гендерная и профессиональная идентичность: теория и методы диагностики. М. : Моск. псих.-соц. ин-т. $128 \mathrm{c}$.

Шубкин В. Н., Бабушкина Т. А., 1986. Оценка профессии: общее и специфическое // Выбор профессии: мотивы и их реализация. М. : Знание. С. 27-52.

Щербакова М. П., 2015. Профессиональная идентичность профессорско-преподавательского состава высших учебных заведений МВД России : автореф. дис. ... канд. социол. наук. Нижний Новгород. 19 с.

Эриксон Э., 2006. Идентичность. Юность и кризис. М. : Флинта. 342 c.

Freidson E., 1970. Profession of Medicine: A Study of Sociology of Applied Knowledge: with a new afterword. Chicago : University of Chicago Press. $440 \mathrm{p}$.

Gudykunst W. B., 2012. Bridging Differences: Effective Intergroup Communication. 4th ed. Thousand Oaks, CA : Sage Publications. 448 p.

Jenkins R., 2008. Social identity. Key ideas. $3^{\text {rd }}$ ed. London : Routledge. 256 p.

Marcia J. E., 1993. The ego identity status approach to ego identity // Ego Identity: A Handbook for Psychosocial Research / Marcia J. E., Waterman A. S., Matteson D. R., Archer S. L., Orlofsky J. L. New York : Springer-Verlag. P. 3-41.

Orlofsky J. L., Marcia J. E., Lesser L. M., 1973. Ego identity status and intimacy versus isolation crisis of young adulthood // Journal of Personality and Social psychology. Vol. 27, № 2. P. 211-219.

Parsons T., 1966. Essays on Sociological Theory. Revised Edition. New York : The Free Press. $460 \mathrm{p}$.

Waterman A. S., 1982. Identity development from adolescent to adulthood: an extension of theory and review of research // Development psychology. Vol. 18, № 3. P. 341-358.

\section{REFERENCES}

Aznacheeva E.N. (ed.), 2012. Introduction. Linguistic Aspects of Individual Identity Study in a 
Changing World: Collective Monograph. Chelyabinsk, Entsiklopediya Publ., pp. 4-7.

Akbarjan F.E., 2009. On the Problem of Self-Esteem and Its Connection to Religious Identity of Teenagers. Voprosy filologicheskikh nauk, no. 5, pp. 217-222.

Batnasunov A.S., 2014. Ethnic Identity of Youth in a Polyethnic Region as a Component of Civil Identity. Mir nauki, kultury, obrazovaniya [The World of Science, Culture, Education], no. 3 (46), pp. 298-299.

Voevoda E.V., 2012. Contact Languages in the PostSoviet Space: Linguistic and Cultural Dominance. Vestnik MGIMO-Universiteta [Vestnik MGIMOUniversity], no. 6 (27), pp. 172-175.

Ganeeva E.I., 2008. Inconstant Social Identity: The Essence and Conditions of Genesis. Vestnik Nizhegorodskogo universiteta im. N.I. Lobachevskogo [Vestnik of Lobachevsky University of Nizhni Novgorod], no. 1 (9), pp. 39-45.

Giddens E., 2005. Formation of the Society: Abstract of the Structuration Theory. Moscow, Akademicheskiy Proekt Publ. $528 \mathrm{p}$.

Danilova E., Yadov V., 2004. Contextually Labile Social Identity as a Norm of Modern Dynamic Societies. SOTSIS [SOCIS], no. 10, pp. 27-30.

Denisova O.V., 2008. Formation of the Professional Identity of a Medical Student within the Educational Framework of the University. Cand. psychol. sci. abs. diss. Ekaterinburg. 26 p.

Didkovskaya Ya.V., 2014. The Career Strategy Dynamics of Youth under the Conditions of Transforming Professional Self-Identification Model. Izvestiya Uralskogo federalnogo universiteta. Seriya 1: Problemy obrazovaniya, nauki i kultury, vol. 126, no. 2, pp. 117-131.

Didkovskaya Ya.V., 2016. Transformation of the Social Correlation Mechanism of Professional SelfIdentification and Professional Career in the Russian Society. Dr. sociol sci. diss. Ekaterinburg. 327 p.

Ermolaeva E.P., 2001. Professional Identity and Marginalism: Conceptions and Reality. Psikhologicheskiy zhurnal, vol. 22, no. 4, pp. 51-59.

Zhernovaya O.R., 2016. Modern Image of "British" Scots in English Jokes and Anecdotes in the Context of National and Cultural Identities' Opposition. Sovremennye issledovaniya sotsialnykh problem [Russian Journal of Humanities], no. 3-2 (27), pp. 175-194.

Zhiginas N., 2007. Stages of Professional Identity Formation of a Teacher. Vysshee obrazovanie $v$ Rossii [Higher Education in Russia], no. 8, pp. 121-122.
Zagumennov A.V., 2017. The Linguistic Personality from the Viewpoint of Hermeneutics and Phenomenology: Problem Statement. Vestnik Volgogradskogo gosudarstvennogo universiteta. Seriya 2, Yazykoznanie [Science Journal of Volgograd State University. Linguistics], vol. 16, no. 1, pp. 144-153. DOI: 10.15688/jvolsu2.2017.1.15.

Zakovorotnaya M.V., 1999. A Person's Identity: SocioPhilosophical Aspects. Rostov-on-Don, Izd-vo Severo-kavkazskogo nauchnogo tsentra vysshey shkoly. $200 \mathrm{p}$.

Zakovorotnaya M.V., 2014. Professional Identity as a Key Aspect of the Modern Social Identity. Vestnik Adygeyskogo gosudarstvennogo universiteta [Bulletin of the Adyghe State University], no. 3 (144), pp. 13-22.

Zeer E.F., Symanyuk E.E., 2005. Psychology of Professional Destructions. Moscow, Akademicheskiy proekt Publ.; Ekaterinburg, Delovaya kniga Publ. 240 p.

Ionova S.V., 2017. Aspects of Studying Written Text as an Object of Forensic Linguistic Expertise. Vestnik Volgogradskogo gosudarstvennogo universiteta. Seriya 2, Yazykoznanie [Science Journal of Volgograd State University. Linguistics], vol. 16 , no. 2 , pp. 28-38. DOI: 10.15688/jvolsu2.2017.2.3.

Isaeva D.A., 2013. Personal and Professional Identity Features in Adolescence and Early Adulthood. Vestnik Sankt-Peterburgskogo universiteta. Seriya 12. Psikhologiya. Sotsiologiya. Pedagogika, no. 2, pp. 78-85.

Kolmogorova A.V., 2016. Terms as a Tool for Construction of Identity in Professional Communication. Vestnik Chelyabinskogo gosudarstvennogo universiteta [Bulletin of Chelyabinsk State University], no. 4 (386), pp. 69-73.

Korneeva V.A., 2016. Sports Symbols as a Means of Formation and Transformation of Political Identity of Regions. Politicheskaya lingvistika [Political Linguistics Journal], iss. 1 (55), pp. 93-98.

Krasnikova Yu.V., 2015. The Structure and Content of Professional Identity of Future Specialists in the Educational Environment of the Technical Secondary School. Professionalnoe obrazovanie $v$ Rossii i za rubezhom [Professional Education in Russia and Abroad], no. 4 (20), pp. 67-73.

Kurakina N.A., 2014. The Influence of Gender Identity Crisis on the Expression of Complimentary Utterances by the Representatives of the English, American and Russian National Identities. Filologicheskie nauki. Voprosy teorii i praktiki [Philological Sciences. Issues of Theory and Practice], no. 5(35), part 2, pp. 122-126. 
Leskova I.V., 2008. Transformation of Social Identity in the Russian Society: Sociological Analysis. Moscow, Soyuz Publ. 374 p.

Aznacheeva E.N. (ed.), 2012. Linguistic Aspects of Individual Identity Study in a Changing World: Collective Monograph. Chelyabinsk, Entsiklopediya Publ. 232 p.

Malyutina T.V., 2014. Professional Identity, Its Structure and Components. Omskiy nauchnyy vestnik [Omsk Scientific Bulletin], no. 5 (132), pp. 149-152.

Markova A.K., 1996. Psychology of Professionalism. Moscow, Znanie Publ. 312 p.

Mironova S.P., 2015. Modern Innovation Technologies of Forming Professional Identity in the System of Higher Education. Ekaterinburg, Izd-vo Rossiyskogo gosudarstvennogo professionalnopedagogicheskogo universiteta. $179 \mathrm{p}$.

Mukhortova V.N., 2015. Features of the Sociological Approach to the Concept of Professional Identity. Sotsium i vlast [Society and Power], no. 3 (53), pp. 9-13.

Patyrbaeva K.V., 2012. Identity: Socio-Psychological and Socio-Philosophical Aspects: Collective Monograph. Perm, Permskiy gosudarstvennyy natsionalnyy issledovatelskiy universitet. $250 \mathrm{p}$.

Razlogov K.E., 2015. Identity Metamorphosis. Voprosy filosofii, no. 7, pp. 28-40.

Romanenko N.M., 2014. Acculturation in the Professional Activities of Specialists in International Relations. Vestnik MGIMOUniversiteta [Vestnik MGIMO-University], no. 4 , pp. 312-316.

Semenenko I.S., 2017a. The Category of Identity in Social Sciences: Notion, Cognitive Potential, Priorities of Research. Identichnost: Lichnost, obshchestvo, politika. Entsiklopedicheskoe izdanie [Identity: Personality, Society, Politics. Encyclopedic Edition]. Moscow, Ves Mir Publ., pp. 18-32.

Semenenko I.S., 2017b. Introduction. Identichnost: Lichnost, obshchestvo, politika. Entsiklopedicheskoe izdanie [Identity: Personality, Society, Politics. Encyclopedic Edition]. Moscow, Ves Mir Publ., pp. 11-17.

Solnyshkina M.I., Ismagilova A.R., Shigapova F.F., 2015. Liberalism in Ergonomicon as a Threat to LinguaCultural Identity (the Case of Modern Kazan). Vestnik Volgogradskogo gosudarstvennogo universiteta. Seriya 4, Istoriya, Regionovedenie, Mezhdunarodnye otnosheniya [Science Journal of Volgograd State University. History. Area Studies. International Relations], no. 5 (29), pp. 34-39. DOI: 10.15688/jvolsu2.2015.5.4.

Solnyshkina M.I., Shigapova F.F., Gabdrakhmanova R.R., 2015. Linguisctic Markers of Linguo-Ethnical and
Professional Identity. Filologiya $i$ kultura [Philology and Culture], no. 4 (42), pp. 150-156. Sukhova E.N., 2013. Transformation of Socioprofessional Identity in Medicine: Cand. sociol sci. abs. diss. Nizhny Novgorod. 22 p.

Fedorov A.V., 2017. A Pedagogical Model of Shaping Professional Identity of Undergraduate Students of Social Work at University. Globalnyy nauchnyy potentsial [Global Scientific Potential], no. 8 (77), pp. 10-12.

Fedotova L.M., 2009. Common Patterns of Professional Identity Forming. Almanakh sovremennoy nauki i obrazovaniya [Anthology of Modern Science and Education], no. 10, part II, pp. 118-120.

Tsapko M.I., 2017. Language Identity as Unifying Identity: in Search of Constructive Methodological Strategies. Yazyk i kultura v epokhu integratsii nauchnogo znaniya $i$ professionalizatsii obrazovaniya: Materialy mezhdunarodnoy nauchno-prakticheskoy konferentsii, pp. 229-235.

Cherednichenko G.A., 2014. Educational and Professional Directions of the Youth. Moscow, CSP i M Publ. 560 p.

Shneyder L.B., 2007. Personal, Gender and Professional Identity: Theory and Methods of Dianostics. Moscow, Moskovskiy psikhologosotsialnyy institut. $128 \mathrm{p}$.

Shubkin V.N., Babushkina T.A.,1986. Profession Assessment: General and Specific. Vybor professii: motivy i ikh realizatsiya [Choosing a Profession: Motives and Their Realisation]. Moscow, Znanie Publ., pp. 27-52.

Shcherbakova M.P., 2015. Professional Identity of Faculty Members of Higher Education Institutions of Ministry of Internal Affairs of the Russian Federation. Cand. sociol. sci. abs. diss. Nizhniy Novgorod. $19 \mathrm{p}$.

Erikson E., 2006. Identity. Adolescence and Crisis. Moscow, Flinta Publ. 342 p.

Freidson E., 1970. Profession of Medicine: A Study of Sociology of Applied Knowledge: with a new afterword. Chicago, University of Chicago Press. $440 \mathrm{p}$.

Gudykunst W.B., 2012. Bridging Differences: Effective Intergroup Communication. Thousand Oaks, CA, Sage Publications. 448 p.

Jenkins R., 2008. Social identity. Key ideas. $3^{\text {rd }}$ ed. London, Routledge. 256 p.

Marcia J.E., 1993. The ego identity status approach to ego identity. Marcia J.E., Waterman A.S., Matteson D.R., Archer S.L., Orlofsky J.L., eds. Ego Identity: A Handbook for Psychosocial Research. New York, Springer-Verlag, pp. 3-41.

Orlofsky J.L., Marcia J.E., Lesser L.M., 1973. Ego identity status and intimacy versus isolation crisis of young adulthood. Journal of 


\section{ДискУССиИ}

Personality and Social psychology, vol. 27, no. 2, pp. 211-219.

Parsons T., 1966. Essays on Sociological Theory. Revised Edition. New York, The Free Press. 460 p.
Waterman A.S., 1982. Identity development from adolescent to adulthood: an extension of theory and review of research. Development psychology, vol. 18, no. 3, pp. 341-358.

\section{Information about the Authors}

Aleksandr Yu. Bagiyan, Candidate of Sciences (Philology), Associate Professor of Department of English Language and Professional Communication, Pyatigorsk State University, Prosp. Kalinina, 9, 357532 Pyatigorsk, Russia, alexander.0506@mail.ru, https://orcid.org/0000-0002-3455-0516

Tatyana A. Shiryaeva, Doctor of Sciences (Philology), Professor, Head of Department of English Language and Professional Communication, Pyatigorsk State University, Prosp. Kalinina, 9, 357532 Pyatigorsk, Russia, shiryaevat@list.ru, https://orcid.org/0000-0001-5508-8407

\section{Информация об авторах}

Александр Юрьевич Багиян, кандидат филологических наук, доцент кафедры английского языка и профессиональной коммуникации, Пятигорский государственный университет, просп. Калинина, 9, 357532 г. Пятигорск, Россия, alexander.0506@mail.ru, https://orcid.org/0000-00023455-0516

Татьяна Александровна Ширяева, доктор филологических наук, профессор, заведующая кафедрой английского языка и профессиональной коммуникации, Пятигорский государственный университет, просп. Калинина, 9, 357532 г. Пятигорск, Россия shiryaevat@list.ru, https://orcid.org/ 0000-0001-5508-8407 